\title{
Can Differentiated Instruction Create an Inclusive Classroom with Diverse Learners in an Elementary School Setting?
}

\author{
Suleyman CELIK \\ Faculty of Education, Tishk International University, Erbil44001, Iraq
}

\begin{abstract}
Learners vary greatly in as far as experience, socioeconomic status, culture, ethnicity, learning styles and cognitive ability are concerned. Such diverse learners bring their own learning and personal character to the classroom, which influence the classroom atmosphere, time management, content to be taught and the educator's teaching style. Different types of instructional methods should be applied to meet all the learners' needs and improve their strengths, and the natural diversity in the classroom should not prevent any learner from achieving the instructional goals. When all students are thoroughly engaged in the learning environment and the instructional methods are adapted to suit the different learners, the teacher manages to establish an inclusive classroom environment. One approach towards creating an inclusive classroom is differentiated instruction. Hence, an action research study was conducted with fifth grade students from the private Ronaki Hawler Primary School in Erbil, Iraq, to find out how differentiated instruction may build an inclusive environment in their classroom. The results of the research were significant and showed that when students are provided differentiated instruction that meets their needs, a tipping point can be reached. Moreover, differentiated instruction helped the teacher to establish a positive learning environment.
\end{abstract}

Keywords: comprehensive, differentiated instruction, diversity, inclusive, interest, positive climate

DOI: $10.7176 / \mathrm{JEP} / 10-6-05$

\section{Introduction}

Teaching is not merely the transmission of knowledge from the sources of knowledge to students through teachers - it also requires the interaction of teachers with learners. However, significant challenges and contradictions in today's classrooms often hamper the teaching and learning process. For example, some students achieve poor grades and others do well, even though they have the same teacher who is skilled at transmitting the content of the day's lesson. In addition, some students want to learn, whereas others do not even want to come to school; some students want to do extra work and others do little at all; some students are actively engaged in the learning process while others are indifferent or bored. These typical challenges, which are the result of the individual differences that exist in every classroom, clearly influence the outcomes of teaching - regardless of how adept a teacher may be at transmitting the contents of the day's lesson.

If positive and inclusive classrooms are to be created, teachers should be aware of the diversity of learners, which is, according to Groundwater-Smith (2009:54), "the range of differences that encompass such cultural factors as ethnicity, language, ability and special needs". However, many more factors are involved. Most students fall into more than one category and may even demonstrate characteristics from several categories (Tomlinson, 2014). They vary in respect of cognitive, affective and physical features; differences due to gender, ethnicity, learning style, language, or creative potential; differences due to exceptionalities and at-risk characteristics; and others. Thus, an effective teacher should be aware of all these factors and attempt to be as inclusive as possible in the classroom. An awareness of student diversity immediately presupposes an awareness of how each learner learns. As not all learners are alike, their learning preferences also differ (Tomlinson, 1999; Tomlinson, 2003). This diversity should be taken into consideration when trying to engage students with the lesson, which is one of the most challenging aspects of teaching. Diversity can however also be a positive resource in the classroom and is something to be embraced (Davies, 2006). Having all the different students participate in the classroom activities makes the classroom an inclusive learning atmosphere where all learners take part in and join the lesson.

An inclusive education set-up is described (Allen \& Cowdery, 2011) as one where everybody has a place and is allowed to participate. In an inclusive classroom, everybody is constantly learning because it is a positive social learning environment where learners have a place and have roles to learn. In such a positive community, students fulfil not only the academic requirements and learner outcomes, but they also learn how to get along with each other (Salend, 2010). They furthermore learn how to manage conflict, acquire a wide variety of citizenship skills and knowledge related to learning, and learn how to work and live together. According to Terrell and Lindsey (2008), one of the greatest features of inclusive education is that it gives the schools and classrooms concerned a unique personality; thus people pay attention and are responsive to what's going on in the classrooms. There is not only a strong and positive learning atmosphere in inclusive classrooms, but learners and teachers are also bound together by strong emotional ties and almost become a community and family. To build a climate like that, a variety of lesson plans, which include positive outcomes for all the learners, should be 
prepared.

According to Alexander, Johnson, Leibham and Kelley (2008), the term inclusive education has taken on the meaning of 'including children with disabilities in regular classrooms for children without disabilities'. In the current study, inclusive means including all children who are affected by intrinsic and extrinsic factors such as low socio-economic status, unsafe environment, uninvolved parents, weak healthcare, inadequately qualified and too few teachers (Engelbrecht, Oswald, \& Forlin, 2006), excluded from school (e.g. if they don't speak the local language of instruction or belong to a different religion), and being at risk of dropping out of school due to sickness, being hungry, not achieving well, or operating at a low cognitive level. It also refers to the inclusion of girls who are pregnant, children affected by certain diseases, and girls and boys who should be in school but are not, especially those who work elsewhere to help their families to survive.

\subsection{Creating a supportive, caring environment}

According to research conducted by Engelbrecht, Oswald and Forlin (2006) in South Africa, inclusive education seeks to ensure all available support from school authorities. These authorities are to establish collaboration among the staff, the community, the family, educational institutions, health services and community leaders in an attempt to build a creative environment and respond to the diverse needs of students. By providing appropriate curricula and organisational arrangements, inclusion should also ensure quality education, regardless of whether students are with or without learning disabilities. The teachers working in the inclusive classrooms should use appropriate teaching strategies and resources, and they should build a partnership with their communities. In their comparative research, Nel, Muller, Hugo, Helldin, Backman, Dwyer and Skarlind (2011) suggested that in order to implement inclusive education effectively in the classroom, the mindset of teachers have to change accordingly. They argued that some South African teachers did not feel adequately equipped to teach in such classrooms.

Another definition of an inclusive school is one that honours and supports all its students (Burden \& Byrd, 2007). Walton, Nel, Hugo and Muller (2009) also define inclusive regular schools as a means of combating discrimination and achieving education for all in a cost-effective way. Inclusiveness is about creating a supportive community around all of our students and breaking down the 'barriers to learning'. It's really about a firm belief that "all learners can learn" (Engelbrecht, Nel, Nel \& Tlale, 2015) and should be afforded the opportunity to work with each other, regardless of dis/ability, race, ethnicity and sexuality (Bennett, 2001).

\subsection{Celebrating diversity}

In inclusive classrooms, no discrimination is made between students who have disabilities and those without disabilities. Since each student contributes to the rich variety of ideas and actions in the classroom, all should be welcomed and appreciated, and the diversity that is reflected in the classroom should be valued. In turn, the students will feel appreciated rather than different, which will make them feel more comfortable and at ease. This feature is the nature of an inclusive classroom. Both the presentation of the curriculum and the assessment of the programmes are designed to meet the students' needs and should help them to achieve the set learning outcomes and reach the goals of the lesson.

\subsection{Responding to all students enthusiastically}

According to the study conducted by Engelbrecht, Nel, Nel and Tlale (2015), teachers' perspectives on and perceptions of an inclusive classroom influence students' engagement with a positive and inclusive learning environment. When Anderson (2007) defines the teacher's task, he indicates that the teacher should not have to figure out whether a student should be participating; it is the teacher's task to figure out how the student should participate. When teachers include students, they consider how to make their schools responsive to every learner who walks in the door; how to really appreciate, identify and honour the individuality and uniqueness of each learner; and how to provide appropriately challenging education for all (Huang, 2002). That is because they try to align everything they do with their vision of being truly integrated socially. All the learners have the right and deserve the chance to be in those classrooms, to be given opportunities, to show who they are and what their strengths are, and to build on those as human beings.

However, despite its benefits and advantages, inclusive education is also hampered by a number of constraints. Maybe the most important constraining issue is the cost of the resources required by this educational model. Financial support should be adequate to provide in all the needs of the inclusive schools, classrooms, teaching and learning processes, and staff training. Developing countries such as South Africa, Kosovo, Turkey and the Kyrgyz Republic are especially having difficulties due to the financial implications of inclusive education (Nel et al., 2011).

So far, many frameworks have been designed to create an inclusive learning atmosphere for the diverse learners and also to help them to identify their learning styles. Differentiated instruction is a framework in which the teacher constantly changes the content (i.e. the curriculum, materials and approaches used to teach the 
content), processes (i.e. the instructional activities or approaches used to help students to master the curriculum) and products (i.e. the assessment tools through which students demonstrate what they have learnt), according to the students' level of ability and needs.

\section{Differentiated Instruction}

Understanding the source of diversity is not enough to teach effectively. This information should be used as the basis of many classroom decisions when building a positive and caring learning environment, selecting a responsive curriculum, determining instructional strategies and providing assistance. All these factors should be combined to yield differentiated instruction, in other words teachers can differentiate their teaching ways when planning lessons, grouping the students, using instructional activities and materials, identifying assignments and determining the type of assessment to use (Borich, 2008). Differentiated instruction can be effective if it responds to the needs and interests of the whole class or of a group of learners in the same classroom, who may all achieve different degrees of academic success. Differentiated instruction is based on the premise that instructional approaches should also vary according to the individual whose academic success is or could be enhanced by a more targeted and individualised approach (Tomlinson, 2000).

In order to provide differentiated instruction, the teacher should know the learners' learning history, background, prior knowledge, readiness to learn, interests, and acquired skilled sets. Based on these, teachers should tailor their instructional strategies for a small group or for an individual learner to speed up academic success (this might be slowed down if only large-group instruction is available). Patterson, Connolly and Ritter (2009) suggested that the goal of differentiated instruction is to maximise each student's personal growth and academic success by meeting each student at his/her current level and guiding him/her to the next step on the learning ladder.

Differentiated instruction is a buzzword that is used continually in education nowadays. Teaching used to be a little like bowling, trying to roll a ball down the middle and getting most of the students. In general, this is a very traditional idea of what teaching is. However, differentiated instruction implies that the teacher is not just serving students in the middle. He/she needs to serve all of the students; those in the middle and those on both ends of the learning spectrum (Watts-Taffe, Broach, Marinak, McDonald Connor \& Walker-Dalhouse, 2012).

Tomlinson (2004) argues that three elements of the curriculum - the content, processes and products - can be differentiated to make instruction more responsive to the individual needs of learners. She also mentions that differentiation occurs when teachers vary the content of their instruction, the processes that students follow, and the products that are created to establish an inclusive classroom environment.

Presenting information in a variety of ways ensures that more students have the opportunity to comprehend what the teacher teaches them. When teachers vary the environment in the classroom, they can change both the physical objects used in the classroom, or the habits and routines that are followed there. Teachers can change the environment by using strategies such as flexible seating to allow students to work where they are most comfortable. Teachers can establish a growth mindset to help students understand learning as a series of goals to be accomplished, instead of grades to be achieved. Students can develop risk-taking skills, independent thinking and collaboration skills as they co-construct their learning with the assistance of their classroom community to vary the process.

It begins with focusing on allowing the students to choose how they will complete the set of criteria by offering them options and choice, and giving them ownership of their own learning. They do not simply receive the instruction, but also participate actively in the construction of their learning. Some scholars call this approach inquiry-based learning (Applebee, Langer, Nystrand \& Gamoran, 2003; White, Shimoda \& Frederiksen, 1999).

Differentiated learning tasks consider the learning preferences, interests and readiness of the students. Teachers need to ensure that these features of differentiation trickle down through their teaching and learning cycles and affect their planning instruction and assessment. Learning happens best when a learning experience pushes the learner beyond his/her independence level (Tomlinson, 2001;8) implies that student readiness is important for differentiation. Differentiated instruction must be working in the student's zone of proximal development and the teacher must understand where the student currently is, where he/she needs to go and what steps need to be taken. Therefore, differentiated instruction is ideally suited for a heterogeneous classroom (Brophy, 1998), in which learning histories, learning styles, learner interests, skills, as well as disabilities (that represent special populations) may impair learning.

Assessing the students frequently will help the teacher to determine where they are and what they need. First of all, a culture of high expectations for all students needs to be introduced. Understanding that every student can achieve, regardless of learning barriers or challenges that they may encounter, ensures that students receive the same opportunities to develop their higher-order thinking. It is not only gifted and talented learners who are capable. Thus, it is essential to ensure that all students have the opportunity to express higher-order thinking skills, and teachers need to figure out a way to allow this to happen. 
Table 1: Overview of and Key Concepts for Differentiated Instruction

\begin{tabular}{|c|c|c|}
\hline Areas & \multirow{2}{*}{\multicolumn{2}{|c|}{$\begin{array}{l}\text { Examples } \\
\text { - } \quad \text { Texts or novels at more than one reading level } \\
\text { - } \quad \text { Instructions through both whole-to-part and part-to-whole approaches } \\
\text { Different types of educational technologies as a way of conveying key } \\
\text { - } \quad \text { A focus on the principles and key concepts, rather than on the details } \\
\text { - } \quad \text { Different tasks to different-level learners } \\
\text { - }\end{array}$}} \\
\hline $\begin{array}{l}\text { Content: The knowledge, skills } \\
\text { and attitudes related to the } \\
\text { subject and the materials, and } \\
\text { the mechanism through which } \\
\text { learning is accomplished }\end{array}$ & & \\
\hline $\begin{array}{l}\text { Process: Instructional activities } \\
\text { or approaches used to help } \\
\text { students to learn the curriculum }\end{array}$ & $\begin{array}{ll}\text { - } & \text { Optio } \\
- & \text { Optio } \\
\text { - } & \text { For th } \\
\text { - } & \text { Incen } \\
\text { - } & \text { Diffe } \\
\text { - } & \text { Tiere } \\
\end{array}$ & $\begin{array}{l}\text { differing levels of difficulty } \\
\text { sed on differing interests of students } \\
\text { ole class, collaborative groups, small groups or individuals } \\
\text { to learn, based on a student's individual interests } \\
\text { ctivities that seek multiple perspectives on topics and issues } \\
\text { gnments }\end{array}$ \\
\hline $\begin{array}{l}\text { Product: The vehicle by means } \\
\text { of which students demonstrate } \\
\text { what they have learned }\end{array}$ & $\begin{array}{ll}\text { - } & \text { Mo } \\
\text { - } & \text { A n } \\
\text { dem } \\
\text { - } & \text { Ass } \\
\text { - } & \text { Opp } \\
\text { stor }\end{array}$ & $\begin{array}{l}\text { respect } \\
\text { choices for the teacher, such as oral responses, interviews, } \\
\text { ns and formal tests } \\
\text { each learner at his/her level } \\
\text { s to students to express themselves such as by writing a } \\
\text { ig a picture or telling about a real-life experience }\end{array}$ \\
\hline \begin{tabular}{llr} 
Learning & \multicolumn{2}{c}{ Environment: } \\
Classroom functions and \\
feeling
\end{tabular} & $\begin{array}{ll}\text { - } & \text { Rea } \\
\text { - } & \text { Ava }\end{array}$ & $\begin{array}{l}\text { furniture to allow for individual or small-group discussions } \\
\text { of supplies and materials }\end{array}$ \\
\hline
\end{tabular}

Based on the above concepts of inclusive education and differentiated instruction, the author describes in this article how a primary school (fifth grade) English Language teacher used a system of differentiated instruction to create an inclusive classroom in which all the students' needs were met. The teacher used differentiated instruction to engage diverse learners in her English courses and the methods she used provided an opportunity for students to learn in a manner that was compatible with their own learning strengths and preferences. The curriculum was defined in terms of what a student would be able to demonstrate (Anderson, 2007; Tomlinson, 2001, 2004).

\section{Methodology}

This study adopted a mixed method research design, which combines both quantitative and qualitative approaches. The purpose of designing a mixed method research study was to build on the synergy and strength that exist between qualitative and quantitative methods to understand our case fully. So far, many hypotheses about inclusive classroom have emerged. To test these hypotheses in an Iraqi environment, the teacher used statistical data and administered pre- and post-tests, as well as questionnaires. In addition to a deductive approach, she used the inductive method in an attempt to generalise the concept of inclusiveness in her school. She interpreted the results of interviews conducted with students and their parents and tried to understand the relationship between cause (differentiated instruction) and effect (inclusive classroom). She also selected the participants purposefully, based on their inefficiency in the English classroom.

The teacher tried to engage all her students in the lessons without leaving anyone behind. She taught English as a foreign language in the fifth grade in primary school. Her classroom was a unique one that included diverse learners. She tried very hard to engage all her students, so as to improve inclusiveness and develop her students' cognitive skills.

The teacher has taught English Language for five years and has faced many problems regarding students' participation in the lesson. She therefore tried to create a positive learning environment by providing an inclusive classroom. She attempted to find out the root causes of these problems and consequently tried to evaluate and correct her decisions by taking the necessary actions to improve her teaching and students' learning.

Although the number of students in the action research classroom was not too high, the desired development of the students was not very satisfactory. The learning outcomes of the courses weren't being achieved; consequently, classroom management problems surfaced and numerous cases of ill-discipline were reported. There may have been many reasons for this collapse, but the reality was that the needs of students weren't being met.

\subsection{Sample selection}

The subjects described in this article attended an inclusion class at the Ronaki Hawler Primary School, a private 
school serving approximately 600 students in grades one through six. Nearly $75 \%$ of the students at the school were Kurds, 10\% were Arabs, 5\% were Turkish, 5\% were Turkmens and the remainder came from other ethnic groups.

The action research involved 26 students in a fifth grade English Language classroom for three months, and the distribution of the students was the same as that of the school. The specific classroom was a prototype of the whole school, which had Kurdish, Arab, Turkmen, Turkish and Yezidi students whose background information, culture, socio-economic status and cognitive strengths were different from each other.

The subjects were chosen purposefully because they were not functioning at a high-order thinking level in English. They used to come to the school displaying an apathetic mood and often tried to destroy the learning atmosphere in the classroom. When they did not disturb the class, they were either very tired or asleep and clearly not interested in the lesson. It was almost impossible for these students to continue with the curriculum. The level of those students in the class was almost as low as that of learners in the previous grade and many of them were at risk to fail in all subjects. Many of these students were considered a "lost cause" and they seemed to be not motivated.

Their parents were often not involved in the education process and therefore the students were demotivated and experienced barriers to learning.

\subsection{Changing the way of teaching: Differentiating the method of instruction}

After a couple of weeks of seeing very little progress with the students, the teachers at Ronaki Hawler Primary School realised that the problem might be the instructional strategies that they used, not the students. The English teacher evaluated her practices in the classroom and decided that she has been teaching in a very traditional way. She started to differentiate her teaching methods and style by doing the following:

- She kept the focus on the concept, and emphasised understanding and sense making rather than retention or regurgitation of fragmented facts.

- She used ongoing assessments of readiness and interests, and did pre-assessments to identify students who needed more support and those who can leap forward. She did not assume that all students needed the same level or type of assistance.

- She used a system of flexible grouping by sometimes letting her students work alone or in groups, based on their readiness, interests and learning styles. She used whole-group instruction for introducing ideas, planning, or sharing results.

- She saw herself as a guide, helped students to set goals based on their readiness, interests and learning profile, and she assessed the students based on their growth and goal attainment.

- She consistently helped the students in one-on-one sessions in the classroom, helped them to focus on the task or take notes, and provided help when they needed.

The teacher furthermore adopted the following teaching habits:

- Using texts or novels at more than one reading level.

- $\quad$ Presenting instruction by using both whole-to-part and part-to-whole approaches.

- Using texts, computer programmes, videos and other media as a way of conveying key concepts to varied learners.

- Focusing on the teaching of concepts and principles, rather than on all the minute facts about issues.

- Having advanced students work on special, in-depth projects, while the other students work on the general lessons.

- Using varied text and resource materials.

- When re-teaching was necessary, altering the content and delivery based on student readiness, interests, or learning profile.

- Providing various types of support for learning, such as using study buddies, note-taking organisers or highlighted printed materials.

- Giving the students choices about how to express what they have learned in a project (e.g. create a newspaper article or report, display key issues in some type of graphic organiser).

- Allowing students to help design products around essential learning goals.

- Providing assignments of varying degrees of difficulty to match student readiness.

- Using a wide variety of assessment types.

- Working with students to develop rubrics that allow for the demonstration of both whole-class and individual goals.

- Providing or encouraging the use of various types of resources in preparing products (Burden \& Byrd, 2007). 


\subsection{Purpose of the research}

The primary purpose of this study was to engage all the above-mentioned students as a sample and to prove that different types of teaching methods can create a system of inclusive education. First, the teacher focused on engaging all the students in the English Language classes and provided them with opportunities to reach a peak, based on their level of ability. By providing differentiated instruction, it was believed that the students' needs could be met and, as a result, they would become more motivated. The teacher also aimed to decrease the classroom management problems to a minimum. So, the aim of the action research was to create an inclusive classroom in which all the students would participate in the courses eagerly. All 26 students eventually took part in the inclusive class run by their English Language teacher. Besides demonstrating a sample of an inclusive classroom, the teacher hoped to set an example that may persuade the school administrators to shift an inclusive school and a safe place in which all the students could achieve to the best of their ability.

\subsection{Research questions}

\section{Main question}

How does differentiated instruction help the teacher to engage all the students and create an inclusive classroom where there is always a learning atmosphere? And, how does the teacher change her teaching style to facilitate more meaningful participation in her English Language classroom?

\section{Sub-questions}

2. Will including all students in the lesson help them to master the content at a higher level?

3. Will creating an inclusive classroom help teachers to minimise classroom management problems?

4. Will creating an inclusive classroom help students to internalise and apply the acquired knowledge in the world around them?

\section{Data Collection and Analysis}

The data was collected from different sources such as a student observation checklist, student questionnaires, student examination results, and interviews. Also, parents were asked whether they noticed any change in their children's learning behaviour. To analyse the data, the teacher's journal was read and a statistical analysis was made of the data obtained through these tools.

Table 2: Triangulation of Data

\begin{tabular}{|c|c|c|c|c|c|}
\hline Research questions & & Data collectiol & instruments & nat were us & \\
\hline $\begin{array}{l}\text { How does differentiated instruction } \\
\text { help the teacher to engage all the } \\
\text { students and create an inclusive } \\
\text { classroom where there is always a } \\
\text { learning atmosphere? }\end{array}$ & $\begin{array}{l}\text { Teacher's } \\
\text { journal }\end{array}$ & $\begin{array}{l}\text { Student } \\
\text { observation } \\
\text { checklist }\end{array}$ & $\begin{array}{l}\text { Student } \\
\text { examination } \\
\text { results }\end{array}$ & $\begin{array}{l}\text { Student } \\
\text { interviews }\end{array}$ & $\begin{array}{l}\text { Student } \\
\text { questionnaires }\end{array}$ \\
\hline $\begin{array}{l}\text { Will including all students in the lesson } \\
\text { help them to master the content at a } \\
\text { higher level? }\end{array}$ & $\begin{array}{l}\text { Student } \\
\text { observation } \\
\text { checklist }\end{array}$ & $\begin{array}{l}\text { Student } \\
\text { questionnaires }\end{array}$ & $\begin{array}{l}\text { Student } \\
\text { examination } \\
\text { results }\end{array}$ & $\begin{array}{l}\text { Student } \\
\text { interviews }\end{array}$ & \\
\hline $\begin{array}{l}\text { Will creating an inclusive classroom } \\
\text { help teachers to minimise classroom } \\
\text { management problems? }\end{array}$ & $\begin{array}{l}\text { Student } \\
\text { observation } \\
\text { checklist }\end{array}$ & & & & \\
\hline $\begin{array}{l}\text { Will creating an inclusive classroom } \\
\text { help students to internalise and apply } \\
\text { the acquired knowledge in the world } \\
\text { around them? }\end{array}$ & $\begin{array}{l}\text { Parental } \\
\text { interviews }\end{array}$ & $\begin{array}{l}\text { Student } \\
\text { questionnaires }\end{array}$ & $\begin{array}{l}\text { Student } \\
\text { observation } \\
\text { checklist }\end{array}$ & $\begin{array}{l}\text { Student } \\
\text { interview }\end{array}$ & \\
\hline
\end{tabular}

\subsection{Teacher's Journal}

While trying to find out the root causes of why the students did not attend classes, the teacher read some of her own journal entries, which could facilitate the creation of a learning atmosphere in the classroom so that all the learners could participate and have their needs met. Reading the notes in her action research journal a couple of months later helped the teacher to create an inclusive classroom by using differentiated methods of instruction.

\subsection{Student Questionnaires}

To identify the problem of students not engaged in the classes and determine ways of engaging them in the lessons, the teacher administered the same questionnaire before and after the action research. The questionnaire was compiled by the teacher and then tailored by the author, based on the literature review. The greatest benefit of the pre-questionnaire was that students' answers informed the teacher about what technique would succeed in engaging them in class - group work; different ways of teaching; easy content, as well as easy and attractive 
assessments (not only quizzes and examinations). Some of the hard-working students preferred to study with a group and from different sources. More than half of the students thought that differentiated instruction would be more motivating, and they thought that they would be more secure in an inclusive classroom. Nearly all the students complained about the current teaching materials and techniques, and they indicated that they were very bored in class.

The post-questionnaire revealed that constant changes with regard to content, process and assessment stimulated the students to become active and more motivated. Working in small groups or pairs, with different contents and experiencing different types of assessments gave the students more confidence and they subsequently increased their grades. At the end of the action research period, the teacher witnessed that using differentiated instruction resulted in creating an inclusive classroom in which all the students were engaged and could participate at their respective levels.

\subsection{Student Observation Checklist}

Student observation based on a checklist served as a useful tool for evaluating the situation in class as the research was conducted. Generally, observations were made not only during classroom time, but during students' free time as well. The teacher kept a diary record to compare the students' behavioural changes as time went on. As the teacher started using differentiated instruction in the form of different contents, different techniques and assessments that met the students' needs, their motivation increased and they were much more eager to participate in the lessons.

\subsection{Student Examination Results}

Learner progress was measured by administering the same proficiency test as a pre-test and post-test. In order to be sure about their progress, the students' mid-term and final exam results, as well as the results of quizzes were taken into account. These examination results enabled the teacher to see how differentiated instruction teaching activities affected the students' progress in English Language courses. An inspection of all these results showed significant improvements in their performance (see Figure 1).

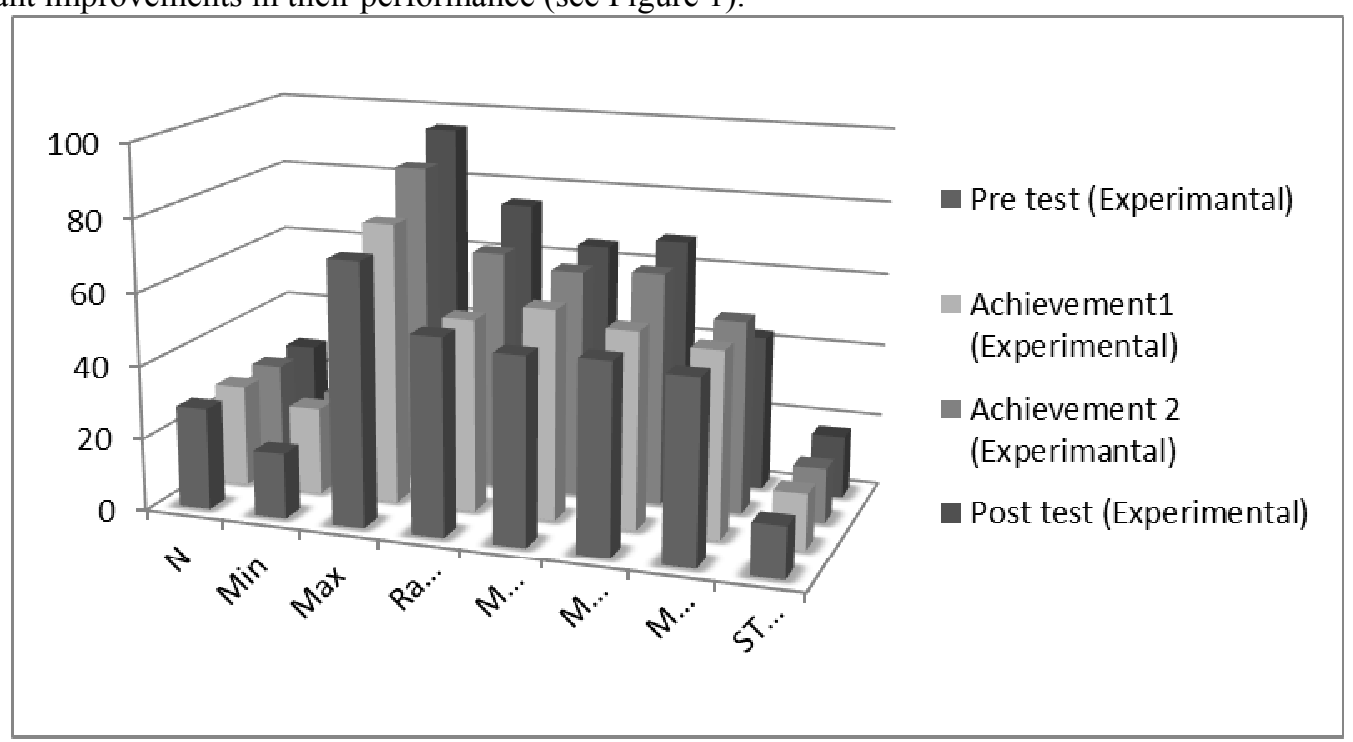

Figure 1: Students' examination results

\subsection{Student Interviews}

After finishing the study, the teacher conducted an interview with the volunteer students in the experimental group. Nine boys and seven girls volunteered to be interviewed in their native language (to avoid the language level impact on the results that were obtained). The main reason for an interview is that it allowed the teacher to speak directly to the students and verify and expand on their answers in the questionnaire and on some other questions. By interviewing, the researcher aimed to explore whether differentiated instruction succeeded in engaging all the students and creating an inclusive classroom where there is always a learning atmosphere. The teacher found that the students were very eager to participate and consequently, their grades improved and the classroom management problems decreased. Most of the students who were interviewed expressed a liking for active participation, change, self-correction and self-reflection - all of which are integrated into lessons in a differentiated classroom. 


\subsection{Parent Interviews}

In order to measure student progress, the teacher interviewed the parents of some of the students. She questioned the parents about changes in the behaviour of their child. The parents told her that their children started to read and speak English in their daily lives. They also indicated that the students became more eager to go to school and they completed their assignments on time. One thing that the parents emphasised is that their children tried to speak, read and listen to the English used in real-world situations such as in the local market, bazaar, etc. They started to help their friends and siblings with their English homework. The interview with the parents demonstrated that the students were likely to use their English in authentic environments if they could continue to participate in inclusive education.

\section{Results}

At the end of the action research study, the teacher gained many helpful insights, which helped her to create a positive learning atmosphere by differentiating her lessons. The answers to the research questions that emerged from the collected data can be summarised as follows:

Main research question: How does differentiated instruction help the teacher to engage all the students and create an inclusive classroom where there is always a learning atmosphere?

Initially the teacher had to cope with different types of learners whose learning needs and interests were totally different. She found it difficult to engage these different learners in the course and as a result, classroom management problems emerged. The first thing that the teacher did to engage all the students in the lessons was to identify the sources of their diversity. Later on, in line with the students' needs, interests, cognitive ability and background, the teacher tried to use different teaching methods, which resulted in differentiated instruction. Students who were interviewed told her that they all liked the new ways of teaching.

Differentiated instruction affords students the opportunity to learn the same content in different ways. The teacher used multiple effective ways to get the same results. In her teaching, she demonstrated flexibility and surrendered the need to control what learning path the students take. What's more, by supporting them on their own path to achieve specific learning goals, the students automatically benefited from individual tailored learning. The gradual release of responsibility helped her to understand that students are ready for independent tasks at different periods. Allowing students to use manipulative or visual organisers to successfully complete tasks was another example of differentiated instruction that the teacher employed. Completing a learning objective at their own reasonable pace was an important achievement for the students; by differentiating the learning process, delivery of the product became quite easy. Changing the content, process and product provided multiple entry opportunities for students to access the same task in different ways. Since the teacher was responsive to student needs at the beginning, the students became eager to attend and participate in the lessons. Consequently, the classroom became an inclusive learning environment in which all the students joined and engaged.

Sub-question 1: Will including all students in the lesson help them to master the content at a higher level? The teacher observed that a differentiated instruction style provided her the opportunity to consider multiple characteristics of the learner and choose an instructional strategy that was suited to a particular learner and learning objectives. From the examination results, it is clear that there was a constant increase in performance and this increasingly motivated the students. Once the students realised that collaborative study brings success, they became more participant. A differentiated instruction style also gave learners alternative pathways by which to learn. Students working below their grade level were given resources to retrace major objectives that have already been taught, while learners working above their grade level were asked to produce work that requires more complex and advanced thinking. By varying teaching techniques and strategies, the teacher made sure that each student had the opportunity to learn in a manner compatible with his/her own learning strengths and preferences. This allowed the students to master the lesson content at a high cognitive level.

The students furthermore demonstrated in their interviews that they managed to identify their interests and uniqueness. They also stated that different types of content and process aroused their interest and motivated them to study.

Sub-question 2: Will creating an inclusive classroom help teachers to minimise classroom management problems?

The inclusive classroom that resulted from differentiated instruction took the form of varying modalities by which students gained access to important learning. The teacher had to present the instruction at different levels and she offered learners a choice with regard to the complexity of the content with which they would begin a learning task. As this matched their current level of understanding, it helped every learner to experience academic success. If students could be offered different learning styles, such as presenting content in incremental steps like rungs on a ladder, this might result in creating a continuum of skill-building tasks. All students benefited from dealing with new information in a variety of ways, for example by listening, reading, and doing. As a result of this general participation, classroom management problems were reduced. 
Sub-question 3: Will creating an inclusive classroom help students to internalise and apply the acquired knowledge in the world around them?

The questionnaire and the parents' interview together revealed that many of the students felt that speaking English socially was a significant issue that furthered social acceptance. From the students' interview, the teacher discovered that the different types of instruction gave the students the necessary self-confidence to talk in public. The classroom environment became less competitive, which helped the students to be interested in the lesson topics. The interviews revealed that the students agreed that it was a good idea to use the learning acquired in the English Language class in authentic situations and this supported to them to learn more.

\section{Conclusion}

As is seen in the research findings, the inclusive classroom provided an effective learning environment in which students felt relaxed and appreciated. The curriculum and teaching methods that were used by the English Language teacher supported student inclusion and development.

The study showed that one teacher changed the mood of education in her classroom where all the students were about to fail. It is not easy to establish an inclusive school, but we can infer from the action research study involved, that if teachers, principals and policy makers were to believe in and provide appropriate conditions for inclusive education, learning and teaching could be made much more effective.

There should however also be support for the students outside the classroom, which means that additional staff will be needed. If the intrinsic and extrinsic barriers to learning can be eliminated, the classrooms, schools and society can be part of inclusive education. Inclusive education does not only need more energy and more time, it also introduces financial challenges to the schools concerned.

Generally, teachers have faced all kinds of difficulties in their classrooms since the days of the one-room schoolhouse. One way of preventing the low-level performance of students in the classroom is to acknowledge learner diversity. Teachers should adjust their expectations and adapt the learning content and activities according to their students' abilities and differences. This is not a disservice to the students when they are given meaningful and appropriately differentiated content that will gradually develop their knowledge. It remains important to have high expectations of all students and to believe that they can all achieve. However, the content should be revised according to the students' level of cognition if they are to participate successfully in an inclusive environment. Students appreciate, feel more relaxed and participate more willingly if the learning content matches their level of reasoning. They also find the inclusive classroom more stimulating and worthwhile compared to a classroom where only high-level content is taught.

Tomlinson (2001) proposes differentiated instruction as one of the solutions to overcome teaching obstacles and create a positive learning atmosphere or an inclusive classroom. To create a true environment of differentiated instruction, student diversity in terms of school-grade readiness, cognitive ability, interests and learning style should be acknowledged. Teachers should set up an inclusive classroom where everybody works towards essential understanding and personal skills development, but where different content, processes and products are used to get there. Differentiation is important but should not be a punitive measure by overloading the teacher.

Regarding students' engagement with and commitment to the courses, differentiation calls on us to take a big leap in the way we think about inclusion. It also stimulates enthusiasm in the teacher, who is more of a facilitator than a strict educator.

Teachers should make decisions to ensure that the curriculum is inclusive, relevant and free of bias. They should select appropriate instructional content to demonstrate that their students are valued as people and that they offer a challenging, yet culturally relevant curriculum. The content may involve the integration of subject areas from diverse traditions, and it may even emerge from students' own questions so that they can construct their own meaning. Teachers may furthermore change the learning activity packages, for example, groups may be formed according to intelligence types. Altering the length, difficulty and time span of assignments can also provide alternative and differentiated instruction. Enrichment activities will also help teachers to create inclusive classrooms.

The differentiated instructional format of teaching for covering the curriculum and creating an inclusive environment worked well in the English Language classroom of the fifth grades of the Ronaki Hawler Primary School. The teacher allowed the students much flexibility, she provided tasks and content relevant to their personal interests, and she helped them to create finished products that reflected their abilities. All of these activities resulted in increased motivation, creativity, pride about the job completed and the whole classroom's engagement with the lesson content.

\section{References}

Alexander, J. M., Johnson, K. E., Leibham, M. E., \& Kelley, K. (2008). The development of conceptual interests in young children. Cognitive Development, 23 (2), pp. 324-334. 
Allen, E. K., \& Cowdery, G. E. (2011). The exceptional child: Inclusion in early childhood education. NY: Delmar Learners.

Anderson, K. M. (2007). Differentiating instruction to include all students. Preventing School Failure, 51 (3), pp. 49-54.

Applebee, A. N., Langer, J. A., Nystrand, M., \& Gamoran, A. (2003). Discussion-based approaches to developing understanding: Classroom instruction and student performance in middle and high school English. American Educational Research Journal, 40 (3), pp. 685-730.

Bennett, H. (2001). Genres of research in multicultural education. Review of Educational Research, 71, pp. 171188.

Borich, G. (2008). Characteristics of effective teaching. In N. Salkind, Encyclopedia of Educational Psychology (pp. 322-326). Thousand Oaks, CA: Sage.

Brophy, J. (1998). Educating teachers about managing classrooms and students. Teaching and Teacher Education, 4 (1), pp. 1-18.

Burden, P. R., \& Byrd, D. M. (2007). Methods for Effective Teaching (4th ed.). Boston, MA: Pearson.

Davies, B. (2006). Subjectification: The relevance of Butler's analysis for education. British Journal of Sociology of Education, 27 (4), pp. 425-438.

DoE. (2001). Department of Education, South Africa. Retrieved 01-12-2018, from https://www.education.gov.za/Portals/0/Documents/Legislation/White\%20paper/Education\%20\%20White \%20Paper\%206.pdf?ver=2008-03-05-104651-000

Engelbrecht, P., Nel, M., Nel, N., \& Tlale, D. (2015). Enacting understanding of inclusion in complex contexts: classroom practices of South African teachers. South African Journal of Education, pp. 1-10.

Engelbrecht, P., \& Oswald, M. \& Forlin, C. (2006). Promoting the implementation of inclusive education in primary schools in South Africa. British Journal of Special Education, 33, pp. 121-129.

Groundwater-Smith, S. (2009). Teacher professional learning in an age of compliance: Mind the gap. (Vol. 2). Springer Science \& Business Media.

Huang, H. (2002). Designing multicultural lesson plans. Multicultural Perspective, 4 (4), pp. 23-31.

Nel, N., Muller, H., Hugo, A., Helldin, R., Backmann, O., Dwyer, H., et al. (2011). A comparative perspective on teacher attitude-constructs that impact on inclusive education in South Africa and Sweden. South African Journal of Education, 31, pp. 74-90.

Patterson, J. L., Connolly, M. C., \& Ritter, S. A. (2009). Restructuring the inclusion classroom to facilitate differentiated instruction. Middle School Journal, 41 (1), pp. 46-52.

Salend, S. J. (2010). Evaluating inclusive teacher education programs: A flexible framework. Changing paradigms and innovative approaches, pp. 130-140.

Terrell, R. D., \& Lindsey, R. B. (2008). Culturally proficient leadership: The personal journey begins within. Corwin Press.

Tomlinson, C. A. (2014). The differentiated classroom: Responding to the needs of all learners. ASCD.

Tomlinson, C. A. (2003). Differentiation in Practice. Cell, 505, pp. 5450-5472.

Tomlinson, C. A. (2001). How to differentiate instruction in mixed-ability classrooms. ASCD.

Tomlinson, C. (2000). Differentiation of instruction in the elementary grades. ERIC Clearinghouse on Elementary and Early Childhood Education.

Tomlinson, C. A. (1999). Mapping a route toward differentiated instruction. Educational Leadership, 57, pp. 1217.

UNICEF. (2014). Financing of Inclusive Education. New York: UNICEF.

Walton, E., Nel, N., Hugo, A., \& Muller, H. (2009). The extent and practice of inclusion in independent schools in South Africa. South African Journal of Education, 29, pp. 105-126.

Watts-Taffe, S., Broach, L., Marinak, B., McDonald Connor, C., \& Walker-Dalhouse, D. (2012). Differentiated instruction: Making informed teacher decisions. The Reading Teacher, 66 (4), pp. 303-314.

White, B., Shimoda, T. A., \& Frederiksen, J. R. (1999). Enabling students to construct theories of collaborative inquiry and reflective learning: Computer Support for Metacognitive Development. International Journal of Artificial Intelligence in Education, 10, pp. 151-182. 